\title{
Comments to the first nomenclature of human cytology: the description of cells and their ultrastructure in the Terminologia Histologica. Which important medical and biological terms are disputable or missing?
}

\author{
Ivan Varga ${ }^{1}$ - David Kachlík ${ }^{2} \cdot$ Luboš Danišovič $^{3} \cdot$ Martin Klein $^{1}$ \\ Received: 15 July 2019 / Accepted: 2 October 2019 /Published online: 12 November 2019 \\ (C) Institute of Molecular Biology, Slovak Academy of Sciences 2019
}

\begin{abstract}
An official and internationally accepted cytological nomenclature has been absent until now. The first internationally accepted nomenclature Terminologia Histologica - International Terms for Human Cytology and Histology, published more than 10 years ago was authored by an ensemble of experts who worked under the auspices of the Federative International Committee on Anatomical Terminology. Terminologia Histologica is a new standard in human cell and tissue terminology. This nomenclature opens with a section dedicated to human cells entitled "Cytologia - Cytology". There are more than 500 terms listed in this section. All Latin terms are accompanied by English equivalents. With regard to synonyms for each term, several have one, two, or, rarely, three. In this opinion article, after a systematic and in-depth analysis of this current internationally accepted cytological nomenclature, we discuss about a missing important cytological terms (e.g., morphological types of nucleoli or mitochondria), missing often used synonymic terms, redundant and unused terms as well as about another disputable terms (e.g., "pigment granules" are in fact membrane-bound vesicles, therefore, the terminology should be changed to "vesicula pigmenti"). We hope that this opinion article will develop a wide scientific discussion before the publication of the second edition, so perhaps the mentioned minor flaws will be corrected, so the new edition of the Terminologia Histologica will become truly an internationally accepted communication tool for most of histologists, including cell biologists.
\end{abstract}

Keywords Terminologia Histologica $\cdot$ Histological nomenclature $\cdot$ Missing terms $\cdot$ Redundant terms $\cdot$ Disputable terms · Ultrastructure

\section{Abbreviations}

FCAT Federative Committee on Anatomical Terminology

FICAT Federative International Committee on Anatomical Terminology

Ivan Varga

ivan.varga@fmed.uniba.sk

1 Institute of Histology and Embryology, Faculty of Medicine, Comenius University in Bratislava, Špitálska 24, SK-81372 Bratislava, Slovakia

2 Department of Anatomy, Second Faculty of Medicine, Charles University, U Nemocnice 3, CZ-128 00 Prague, Czech Republic

3 Institute of Medical Biology, Genetics and Clinical Genetics, Faculty of Medicine, Comenius University in Bratislava, Špitálska 24, SK-81372 Bratislava, Slovakia
FIPAT Federative International Programme for Anatomical Terminology

TH Terminologia Histologica

\section{Introduction}

Terminologia Histologica (TH) is a new standard in human cell and tissue terminology. The first internationally accepted nomenclature Terminologia Histologica, published more than 10 years ago (2008) was authored by an ensemble of experts who worked under the auspices of the Federative International Committee on Anatomical Terminology. Allen (2009) described the significance of its printed version as follows: "Terminologia Histologica contains terminology for cellular structures, tissue and organs at the microscopic level. The books present the Latin term for each structure accompanied 
by the term in current usage in English-speaking countries." This nomenclature opens with a section dedicated to human cells entitled "Cytologia - Cytology". In this section, each structure has its own Latin term, as well as the English counterpart, and of course an original identification number. Many national anatomical societies have already managed to publish a version in their domestic language, including Czech (Belej et al. 2014) and Slovak version (Belej and Belej 2014). This convention copied a trend known previously from the publishing process of the official anatomical nomenclature Terminologia Anatomica (FCAT 1998), which, after the publication of the original version, was translated into many national languages including French (Fabry et al. 2006), Czech (Kachlík et al. 2010), Polish (Gielecki et al. 2008) or Spanish (Duque et al. 2018). Based on this trend, we believe that the original Latin-English version of the Terminologia Histologica, which includes also the description of the cell ultrastructure, has to be the most refined and most accomplished to become internationally accepted and renowned. This urge for perfection is also underlined by the fact that the original version is the base for any subsequent language version.

An official and internationally accepted cytological nomenclature has been absent until now. It is true that some societies of pathologists and cytopathologists have published their own terminologies, but these were focused mostly on the peculiarities of the diagnostic process of oncological diseases. The examples of such cytopathological terminologies are the new "Paris System terminology for urinary cytology" (Courtade-Saïdi et al. 2019), the new terminology in endometrial cytology system (Shinagawa et al. 2018) or the Bethesda system for cervical cytology (Nayar and Wilbur 2017). However, from the point of view of a cytopathologist, this "cancer cells terminology" is actually a mean for cancer screening, diagnosis and management and a tool to provide an effective communication between a laboratory and a clinician. Therefore, these pathological terminologies cannot satisfy the necessity for a proper terminology of normal human cells. According to our knowledge, the only textbooks which fulfil the criteria for a solid resource and a starting-point for the development of future cytological terminology are "Ultrastructure of Mammalian Cell" (Krstić 1979) and "The Dictionary of Cell and Molecular Biology" (Lackie 2013).

We have not attempted to criticize the first edition of the Terminologia Histologica, including the section of the first nomenclature of cytology. We deeply appreciate the endeavour of the team of experts working under the auspices of the Federative International Programme on Anatomical Terminology. Whether it is a textbook or a terminology publication, the first edition is always prone to minor mistakes or missing terms. We hope that this opinion article will develop a wide scientific discussion before the publication of the second edition, so perhaps the mentioned minor flaws will be corrected, so the new edition of the TH will become truly an internationally accepted communication tool for mot of histologists, including cell biologists.

\section{Materials and methods}

A systematic and in-depth analysis of the current internationally accepted nomenclature "Terminologia Histologica: International Terms for Human Cytology and Histology "(FIPAT 2008), with focus on the first section "Cytology". The analysis was focused on finding of missing terms which may be important for experts in the fields of medicine and electron microscopy, or missing synonymic terms which are more often used in every day communication among cytologists. We also discuss the significances of our findings for every-day cytological praxis, for scientists, medical doctors, as well as for university teachers.

\section{Results and discussion}

There are more than 500 terms listed in the section Cytology of the Terminologia Histologica. All Latin terms are accompanied by English equivalents. With regard to synonyms for each term, several have one (cellula praecursoria embryonica; stipoblastus), two (limbus microvillosus; limbus penicillatus; limbus striatus), or, rarely, three (nexus; macula communicans; synapsis non vesicularis; synapsis electrica). In cases where synonyms are listed, the first term is typically preferred by the Federative International Committee on Anatomical Terminology. In our results, the missing terms are marked with bold.

\section{Missing important cytological terms}

In the section External morphology, another three types of cells according to the shape can be added: cellula caliciformis (goblet-shaped cell), e.g. mucus-secreting goblet cell of the intestines or upper airways, cellula piriformis (pear-shaped cell), e.g. neuron purkinjese in the cerebellum, and cellula discoidea biconcava (biconcave disc-shaped cell), e.g. erythrocyte.

In the section Surface specializations, no information is given neither about canaliculus intracellularis (intracellular canalicule), e.g. in the parietal cell of the stomach, nor about labyrinthus basalis (basal labyrinth), e.g. in the epithelial cell of the proximal tubule of the nephron (Fig. 1), or in the striated duct of a salivary gland. Both are surface specializations invaginations of the cell membrane associated with ion transport channels. Even the basal labyrinth is absent in the 


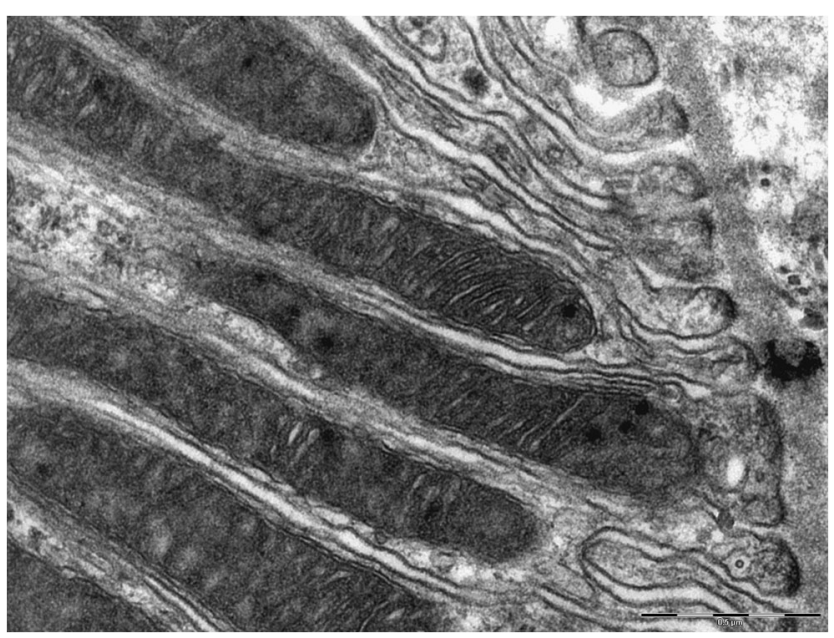

Fig. 1 Basal labyrinth (labyrinthus basalis). Cell membrane invaginations in the basal part of the cell with numerous mitochondria a typical sign of electrolyte and water transporting cells (transmission electron microscope, epithelial cell of the proximal tubule of the kidney, rat, Scale bar $=0.5 \mu \mathrm{m}$ )

Cytology part of TH, it is present in the chapter on Urinary system.

Next, using the transmission electron microscope to visualize brachium dyneini (cilii), we can easily recognize two arms, both very important. In case one or both arms are missing or defected, immotile cilia syndrome occurs (Mitchison and Shoemark 2017; Werner and Kouis 2017). They should be termed brachium dyneini externum (external dynein arm) and brachium dyneini internum (internal dynein arm). Concerning cilium and its ultrastructure, a general term apparatus cilii (ciliary apparatus) should be added comprising all structures associated with the cilium (e.g. axonema, corpusculum basale). Moreover, the ultrastructure of

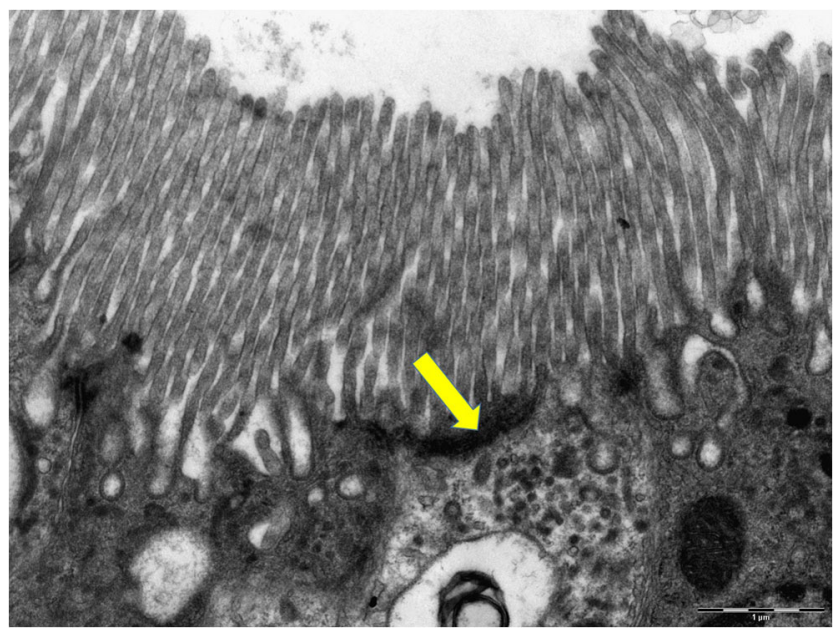

Fig. 2 Terminal web (trama cytoskeletalis terminalis, marked with arrow) of microfilaments beneath the microvilli (transmission electron microscope, epithelial cell of the proximal tubule of the kidney, rat, Scale bar $=1 \mu \mathrm{m}$ ) microvillus and stereocilium is not specified, thus several terms concerning their structure should be added, e.g. filamentum actini (actin filament) and trama cytoskeletalis terminalis (terminal web, Fig. 2).

There is also no information about the different morphological types of the nucleolus. Three types of the nucleolus can be distinguished according to its appearance at the electron microscopic level (Smetana 2011; Busch and Smetana 1970):

- typus compactus (compact type, Fig. 3a) is typical for embryonic and tumour cells with active synthesis of the mRNA;

- typus circularis (ring-shaped nucleolus) is typical for nonactive cells;

- typus reticularis is the nucleolus with nucleolonemas (Fig. 3b), a transition between the two previous types, typical for most somatic cells.

Another missing cytological term is ergastoplasm. Ergastoplasma is the term used to designate a specialized zone of cytoplasm that stains with basic dyes, rich in rough endoplasmic reticulum and ribosomes (Haguenau 1958).

Concerning the mitochondria, there are several missing terms. Chondriom is the term for the whole set of mitochondria in a single cell, visible at the light microscopic level (e.g. with specialized staining). Mitochondria are dynamic organelles with the ability to fuse and fission. The dynamics of the mitochondria should be reflected in the terminology as well: fusio mitochondrii (mitochondrial fusion) and divisio mitochondrii (mitochondrial division / fission) (Karbowski and Youle 2003; Polyakov et al. 2003). Additionally, from the morphological point of view of the inner membrane, mitochondria can be classified as:

- typus tubularis - mitochondria with tubular-shaped invaginations of the inner membrane, typical for steroid hormone-producing cells (Prince and Buttle 2004),

- typus cristalis (mitochondria with cristae; ridge-like invaginations of the inner membrane, typical for the majority of human cells).

- typus intermedialis, an intermediate type, characterized by both tubular and irregular crista-like structured inner membranes (Meinhardt et al. 2000).

- typus saccularis should be suggestive of the mitochondria of the cells of the adrenal gland displaying plenty of ringlike sections of the inner membrane. However, it is questionable, whether the saccular type of mitochondria is present in humans; it was described in some neurons of rats (Hayashida 1973) or in the adrenal gland of hedgehogs (Krstić 1979), but only once in humans (Riva et al. 2003). 

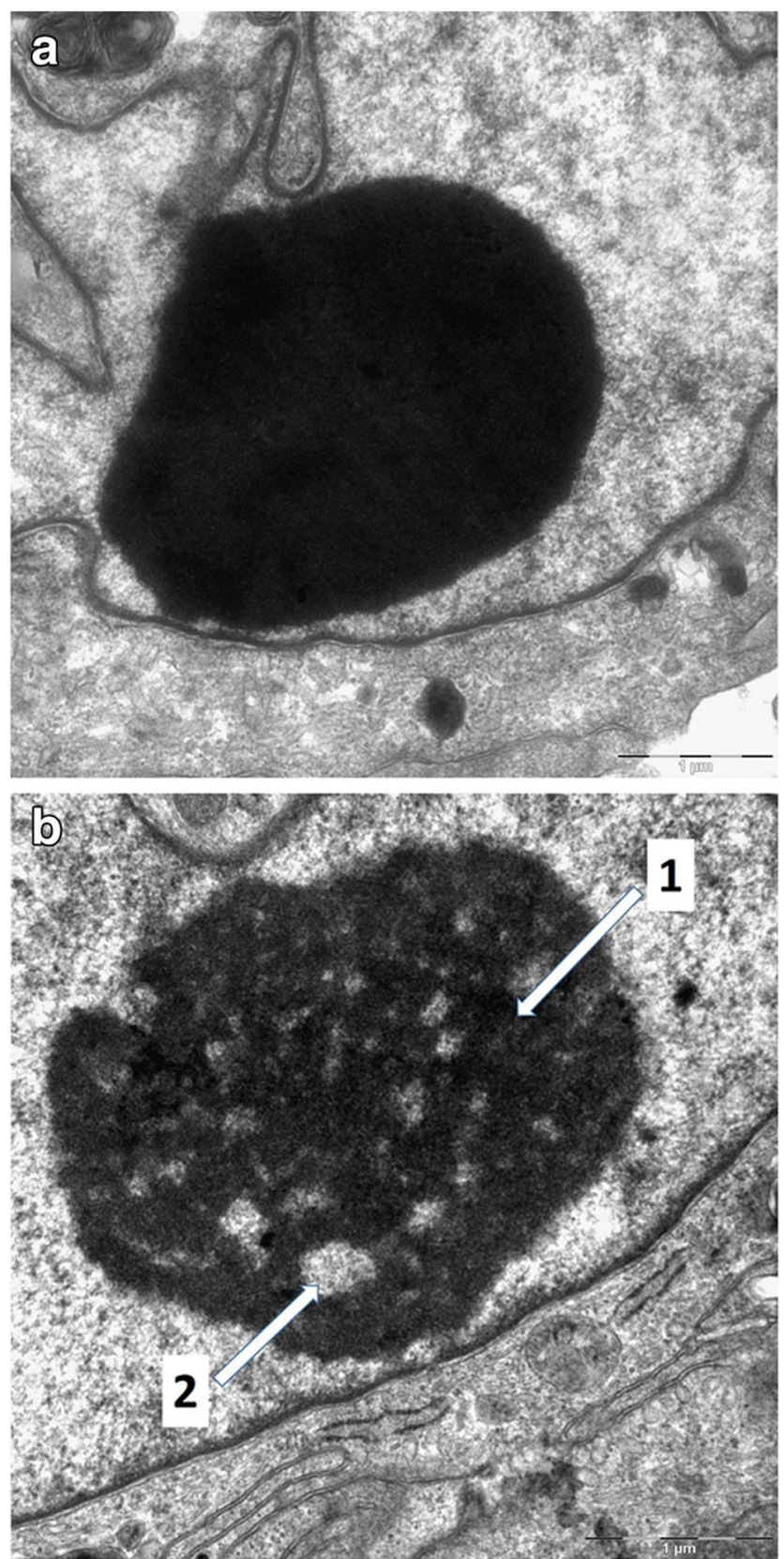

Fig. 3 a. Compact type of the nucleolus (typus compactus), as a typical sign of a cell with active synthesis of the mRNA (transmission electron microscope, cell culture of human adipose tissue-derived mesenchymal cells, Scale bar $=1 \mu \mathrm{m}$ ). b. Nucleolus with nucleolonemas (typus reticularis), a typical nucleus in the majority of somatic cells. 1 . Nucleolonema, a mesh-like arrangement of nucleolar chromatin; 2. Fibrous part (transmission electron microscope, cell culture of human adipose tissue-derived mesenchymal cells, Scale bar $=1 \mu \mathrm{m}$ )

Concerning endocytosis, trogocytosis (from the ancient Greek trogo, meaning "gnaw") which represents a communication tool between immune cells, mesenchymal cells and cancer cells, involving the exchange of large plasma membrane fragments between adjacent cells, is missing in the TH (Dhainaut and Moser 2014; Melzer et al. 2018). Another term of Greek origin, emperipolesis, which means "inside round about wandering" is missing as well. Emperipolesis is a condition, where living and intact cells are seen in the cytoplasm of a host cell without any damage. The cells taken frequently in are neutrophils, lymphocytes and plasma cells. The host cell may be a megakaryocyte, monocyte, endothelial cell, fibroblast, or malignant cell (Gupta et al. 2017).

The terms aster and diaster serve for the morphological description of the events during metaphase and anaphase at the light microscopic level. To be consistent, the terms spirem (spiral) and dispirem (double spiral) for the morphological description of prophase and telophase of the mitotic division should also be added to the TH.

The terms associated with cell death - apoptosis and anoikis are listed, but the terms necrosis and necroptosis, as a form of programmed necrosis (Szobi et al. 2017), are missing.

\section{Missing often used synonymic terms}

There is a synonymic term for inclusiones cytoplasmicae paraplasma - which should be included as the nonpreferred synonym. There can be added a Latin synonym to the list of English equivalents of plasmalemma - membrana plasmatica.

In general description of the cell nucleus the term karyoplasma is used more frequently than nucleoplasma. Karyoplasma is derived from the Greek word karyon (nucleus), similarly to the term cytologia which is also derived from the Greek word kytos (cell), but since the functional centre of the cell is termed nucleus, the related structures should be denominated in a corresponding way. Thus, karyoplasma should be added as the non-preferred Latin synonym to nucleoplasma.

\section{Redundant and unused terms}

The terms cellula uninucleata and cellula mononucleata both describe a cell with only one nucleus, and they are obviously synonyms. They should be merged into one term, cellula uninucleata, in accordance with the other terms related to the number of nuclei within a cell using the Latin prefixes bi- and multi-. The term cellula collumnaris and cellula prismatica both describe a similarly shaped cell (like a column). As synonyms, they should be listed as one term, cellula columnaris. The terms processus amoeboideus and pseudopodium both describe a temporary cytoplasmic process or projection from a cell, which is typical for mesenchymal and immune cells (or in zoology for unicellular protozoa), and these are important for motility and ingestion of nutrients or foreign particles during phagocytosis. These terms seem to be synonyms and should be combined into the term pseudopodium because "amoeboid" is a term primarily associated with zoology. The terms nucleus multilobatus and 
nucleus segmentatus both describe similar arrangements of the nucleus of granulocytes. They should be merged.

The non-preferred Latin term organula as a synonym for organelle is not used in current literature and should be deleted. The structure for the crinophagolysosoma is unclear to the authors because no entry has been found by searching Google and PubMed. Unless this term is complemented with a definition and supported with a citation for a reference book or original article, it should be excluded from the TH. The term processus polypoideus (polypoid process), which is subordinated to the Surface specializations of cell, does not match any known cell in the human body. Thus, it should be deleted from the TH. Also for gamma granulum glycogeni, no entry has been found by searching Google and PubMed. Thus, it should be excluded from the TH.

\section{Another disputable terms}

Granula pigmenti (pigment granules) should be classified in general as granula pigmenti exogena (exogenous pigment granules, e.g. dust particles causing anthracosis, silver particles causing argyrosis or color particles of tattoo ink) and granula pigmenti endogena (endogenous pigment granules). The latter should contain granula melanini (melanin granules, subdivided into granula eumelanini and granula pheomelanini), granula neuromelanini (neuromelanin granules in the cytoplasm of the neurons of substantia nigra, area postrema, trigonum nervi vagi and locus caeruleus), granula lipofuscini (lipofuscin granules mentioned in the part describing lysosomes, but they should be added to the general overview since they represent pigment granules). Another issue concerning the pigment granules is their precise designation - as electron microscopy clearly shows that the vast majority of the mentioned structures are in fact membrane-bound vesicles with more or less granular content. Therefore, the terminology should be altered so that it reflects their exact nature, i.e. vesicula pigmenti (pigment vesicles).

In the subchapter "Cell cycle" the English translation of the term filamentum chromatini is chromatin fibre; more accurate one would be "chromatin filament".

The complicated English term "embryonic stem cell induced artificially in vitro" for cellula precursoria embryonica artificialis (stipitoblastus artificialis) is not frequently used in current literature and should be shortened to induced pluripotent stem cell (iPSC). In PubMed more than 3.500 articles deal with the topic of induced pluripotent stem cells. Similarly, the description of previously known "primary lysosome" is in the recent terminology termed as "vesicula golgiensis transferrens enzymata lysosomatica" and in English "Golgi vesicle transporting lysosomal enzymes", both of which are extremely long and complicated. From our point of view as university teachers of histology, cytology and biology, this new term is really unpractical during teaching. The previous classification of "primary, secondary and tertiary lysosomes" was more logical for students.

\section{Conclusion}

This article anticipates that in the following years the cytological terminology will experience the same strenuous path the anatomical terminology has already endured. The current anatomical terminology has an extensive history, which is the summary of especially long journey, beginning in the first half of the sixteenth century, when Flemish anatomist Andreas Vesalius authored the first widely known anatomical textbook entitled $D e$ humani corporis fabrica published in 1543. The initial knowledge of the microscopic structure of the cells of the human body has been continuously broadening thanks to a number of revolutionary discoveries of twentieth Century. These milestones of the cytology development include the invention of the electron microscope, application of histochemical and immunohistochemical methods into day-to-day research and routine histological and cytological examination (Riva et al. 2014; Wick 2018), and last but not least, the development of molecular biology, whose methods are applicable also in the cytological research. A typical example is flow cytometry which allows scientists to rapidly quantify up to 50 parameters for millions of cells per sample (Montante and Brinkman 2019) or single cell-based methods (Tritschler et al. 2019). All of the aforementioned underlines the status of cytology as constantly developing scientific discipline, with a continuous influx of new knowledge, resulting in an unavoidable necessity to revise the cytological part of the Terminologia Histologica at regular intervals.

The FIPAT mission is to continually adapt its anatomical terminologies to developments in the morphological sciences and to the needs of medicine, the biomedical sciences and other health professions, and to promote the correct use of terminology among these groups, as well as members of the general public, including writers and journalists (Online 1, 2019). By means of this article, we would like to thank the whole team of authors behind the first edition of the Terminologia Histologica for doing a perfect job. Any new terminological suggestion supported with reference, citations, figures can be send to the FIPAT either by individuals or gathered by any national anatomical scientific society. We hope that a wide scientific discussion will develop before the publication of the second edition, so that the new edition of the $\mathrm{TH}$ will become truly an internationally accepted communication tool for most of histologists and cytologists. 


\section{Compliance with ethical standards}

Conflict of interest The authors declare no conflicts of interest. The authors received no financial support for the research, authorship, and/ or publication of this article.

Declaration of informed consent or animal studies This article does not contain any studies with animals performed by any of the authors. The images from transmission electron microscope are from the archive of Institute of Histology and Embryology, Faculty of Medicine, Comenius University in Bratislava.

\section{References}

Belej K, Belej K (2014) Histologické medzinárodné názvoslovie: latinsko-anglicko-slovenské s medzinárodnými číselnými kódmi. Praha, Grada 284 pp. ISBN 978-80-247-4598-5

Belej K, Belej K, Horký D (2014) Histologické mezinárodní názvosloví: latinsko-anglicko-české s mezinárodními číselnými kódy. Praha, Grada 288 pp. ISBN 978-80-247-4599-2

Busch H, Smetana K (1970) The nucleolus. Academic Press, New York

Courtade-Saïdi M, Cochand-Priollet B, Vielh P, Piaton E, Sous l'égide de la Société Française de Cytologie Clinique (2019) A new terminology for urinary cytopathology: The Paris System for Reporting Urinary Cytology (2015). Ann Pathol doi: https://doi.org/10.1016/ j.annpat.2019.04.003

Dhainaut M, Moser M (2014) Regulation of immune reactivity by intercellular transfer. Front Immunol 5:112. https://doi.org/10.3389/ fimmu.2014.00112

Duque J, Vásquez B, del Sol M (2018) Problemática Educativa Terminológica Anatómica en América Latina: Terminologia Anatomica es Internacional, no Nacional ni Regional. Int J Morphol 36(4):1423-1430

Fabry P, Baud R, Burgun A, Lovis C (2006) Amplification of Terminologia anatomica by French language terms using Latin terms matching algorithm: a prototype for other language. Int $\mathrm{J}$ Med Inform 75(7):542-552

FCAT (1998) Terminologia Anatomica. Thieme Verlag, Stuttgart. 292 pp. ISBN 3131143614

FIPAT, Federative International Programme on Anatomical Terminology (2008) Terminologia Histologica: International Terms for Human Cytology and Histology. Lippincott Williams \& Wilkins. 207 pp. ISBN 0781766109

Gielecki J, Zurada A, Osman N (2008) Terminologia anatomica in the past and the future from perspective of 110th anniversary of polish anatomical terminology. Folia Morphol (Warsz) 67(2):87-97

Gupta N, Jadhav K, Shah V (2017) Emperipolesis, entosis and cell cannibalism: demystifying the cloud. J Oral Maxillofac Pathol 21(1): 92-98. https://doi.org/10.4103/0973-029X.203763

Haguenau F (1958) The ergastoplasm: its history, ultrastructure, and biochemistry. Int Rev Cytol 7:425-483

Hayashida Y (1973) Gigantic mitochondria of spinal ganglion cells in rat. Cytobiologie 7(3):289-296

Kachlík D, Čech P, Musil V et al. (2010) České tělovědné názvosloví: návrh české anatomické nomenklatury podle poslední revize mezinárodně platné latinské anatomické nomenklatury. Brno, Nákladem autora. 169pp. ISBN 978-80-254-5684-2

Karbowski M, Youle RJ (2003) Dynamics of mitochondrial morphology in healthy cells and during apoptosis. Cell Death Differ 10(8):870 880. https://doi.org/10.1038/sj.cdd. 4401260

Krstić RV (1979) Ultrastructure of Mammaliam cell. Springer-Verlag, Berlin
Lackie JM (ed) (2013) The dictionary of cell and molecular biology. Academic Press, London, 750 pp. isbn:978-0-12-384931-1

Meinhardt A, McFarlane JR, Seitz J, de Kretser DM (2000) Activin maintains the condensed type of mitochondria in germ cells. Mol Cell Endocrinol 168(1-2):111-117. https://doi.org/10.1016/s03037207(00)00308-7

Melzer C, von der Ohe J, Hass R (2018) Concise review: crosstalk of mesenchymal stroma/stem-like cells with cancer cells provides therapeutic potential. Stem Cells 36(7):951-968. https://doi.org/10. 1002/stem.2829

Mitchison HM, Shoemark A (2017) Motile cilia defects in diseases other than primary ciliary dyskinesia: the contemporary diagnostic and research role for transmission electron microscopy. Ultrastruct Pathol 41(6):415-427. https://doi.org/10.1080/01913123.2017. 1370050

Montante S, Brinkman RR (2019) Flow cytometry data analysis: recent tools and algorithms. Int J Lab Hematol 41(Suppl 1):56-62. https:// doi.org/10.1111/ijlh.13016

Nayar R, Wilbur DC (2017) The Bethesda system for reporting cervical cytology: a historical perspective. Acta Cytol 61(4-5):359-372. https://doi.org/10.1159/000477556

Online 1 (2019) http://www.ifaa.net/committees/anatomicalterminology-fipat/fipat-programme/ (March 12, 2019)

Polyakov VY, Soukhomlinova MY, Fais D (2003) Fusion, fragmentation, and fission of mitochondria. Biochemistry (Mosc) 68(8):838-849

Prince FP, Buttle KF (2004) Mitochondrial structure in steroid-producing cells: three-dimensional reconstruction of human Leydig cell mitochondria by electron microscopic tomography. Anat Rec A Discov Mol Cell Evol Biol 278(1):454-461. https://doi.org/10.1002/ar.a. 20019

Riva A, Loffredo F, Uccheddu A, Riva FT, Tandler B (2003) Mitochondria of human adrenal cortex have tubular cristae with bulbous tips. J Clin Endocrinol Metab 88(4):1903-1906. https:// doi.org/10.1210/jc.2002-030013

Riva MA, Manzoni M, Isimbaldi G, Cesana G, Pagni F (2014) Histochemistry: historical development and current use in pathology. Biotech Histochem 89(2):81-90. https://doi.org/10.3109/ 10520295.2013.822559

Shinagawa A, Kurokawa T, Yamamoto M, Onuma T, Tsuyoshi H, Chino Y, Iwasaki K, Mori M, Imamura Y, Yoshio Y (2018) Evaluation of the benefit and use of the new terminology in endometrial cytology reporting system. Diagn Cytopathol 46(4):314-319. https://doi.org/ $10.1002 /$ dc. 23901

Smetana K (2011) The nucleolus through the years. J Appl Biomed 9: $119-127$

Szobi A, Gonçalvesová E, Varga ZV, Leszek P, Kuśmierczyk M, Hulman M, Kyselovič J, Ferdinandy P, Adameová A (2017) Analysis of necroptotic proteins in failing human hearts. J Transl Med 15(1): 86. https://doi.org/10.1186/s12967-017-1189-5

Tritschler S, Büttner M, Fischer DS, Lange M, Bergen V, Lickert H, Theis FJ (2019) Concepts and limitations for learning developmental trajectories from single cell genomics. Development 146(12). https:// doi.org/10.1242/dev.170506

Werner C, Kouis P (2017) Should transmission electron microscopy and ultrastructural cilia evaluation remain part of the diagnostic work-up for primary ciliary dyskinesia? Ultrastruct Pathol 41(6):386-389. https://doi.org/10.1080/01913123.2017.1362089

Wick MR (2018) Diagnostic histochemistry: a historical perspective. Semin Diagn Pathol 35(6):354-359. https://doi.org/10.1053/j. semdp.2018.10.007

Publisher's note Springer Nature remains neutral with regard to jurisdictional claims in published maps and institutional affiliations. 